Obedience and Authority among Muslim Couples: Negotiating Gendered Religious Scripts in Contemporary Indonesia

Sociology of Religion (published online 10 December 2018).

https://doi.org/10.1093/socrel/sry045

This study of Muslim married couples in Indonesia shows that religiously justified scripts about wives' obedience and husbands' household authority are ways of accomplishing gender as well as achieving status as good Muslims. Such scripts are amplified by a context in which a version of Islamic family law that envisions women as primarily domestic and men as household authorities and breadwinners has been institutionalized. However, this vision is also being challenged by women's increasing educational attainment as well as competing egalitarian discourses of gender in Islam. The gendered religious scripts used by Muslim couples compensate for social changes that threaten to reshape both domestic and public life. I propose that how Muslim men and women talk about their marriages and households has become a key mechanism for accomplishing modern Muslim gender identities in a context where men's authority is at risk. These dynamics may be especially prevalent in Muslim contexts where Islamic law is becoming more institutionalized in state bureaucracies and everyday life. 
Recent sociological literature examines how gender and religion are mutually constitutive. As scholarship has shown, not only do people do religion in gendered ways, but they also often do gender in religious ways (Avishai 2008; Irby 2014b; Avishai, Jafar, and Rinaldo 2015; Burke and Hudec 2015; Rao 2015; Darwin 2018; Sumerau, Mathers, and Cragun 2018). As Darwin (2018) observes, in religions with strong gender prescriptions, to practice religion is to do gender. Intimate relationships are a key site for enactments of religion and gender. Yet, while the relationality of gender is well recognized, few recent studies investigate qualitatively the intersections of gender and religion among partners in intimate relationships, and much less is known about couples in Muslim contexts. Building on Bartkowski's (2001) concept of the "tandem negotiation of gender" in Evangelical marriages, this article investigates scripts of wives' obedience and husbands' authority among Muslim couples in urban Indonesia. I extend the literature to show how married women and men use these gendered religious scripts to accomplish their statuses as Muslim men and women.

Ideas about women's submission and men's leadership are not new in Indonesia, the world's fourth largest country and the largest Muslim country by population. Different from the Western contexts in which many sociological studies of religion and gender are situated, Indonesia is a majority Muslim country which has undergone a process of revitalization of Islam. As part of this process, the state's version of Muslim family law has become increasingly influential. This development has coincided with rising rates of women's education and more diverse work opportunities for educated women. Thus, greater institutionalization of Islamic family law coexists with social changes that potentially challenge the gender ideals it promotes.

As this article shows, this context has an important role in shaping couple dynamics such that many married men and women seek to protect or bolster men's status in the household. 
Women tend to emphasize their obedience and underplay their income earning, while men emphasize their authority and family leadership. This process, I argue, compensates for the broader social changes that are occurring and shows that how Muslim men and women talk about their marriages and households has become a key mechanism for accomplishing gender status. This tandem negotiation of gender among Muslim married couples in Indonesia shows that gendered religious scripts (Rao 2015) are crucial to how married Muslim men and women enact gender identities, especially in situations where the conventional gendered order is at risk.

More broadly, this article suggests that as public life becomes more egalitarian, domestic life can become a significant arena for reasserting gender norms. These dynamics may be especially pronounced in Muslim contexts where increased opportunities for women challenge the male breadwinner model embedded in institutionalized versions of Islamic family law.

\section{RELIGION AND GENDER}

Studies of religion and gender have sought to understand religious women's experiences, particularly in conservative religious traditions (Avishai, Jafar, and Rinaldo 2015; Avishai 2016; Avishai and Irby 2017). Scholars such as Bartkowski (2001) and Gallagher (2003) have also studied gender relations among religious married couples. Marriage is an especially significant site for investigation, because conservative religions often emphasize "traditional" gender and family ideals, such as complementarianism (the belief that men and women have naturally different roles and responsibilities). While Evangelical couples rely on the Bible as an essential resource for negotiating gender, Muslim couples may rely on the Qur'an and other Islamic texts, including Muslim family law. These texts and the discourses of religious elites influence scripts that instruct believers how to enact gendered roles and responsibilities. 
This literature shows that religious discourses on gender are complex and flexible. For example, Evangelical women may embrace submission to their husbands as a way to manage relationship difficulties, especially over the division of labor (Griffith 1997; Brasher 1998; Chong 2008). Other recent research suggests that younger Evangelicals may be embracing more mutuality when it comes to gender (Irby 2014a;). Some scholars see Evangelical scripts about women's submission shifting to emphasize a softer form of patriarchy that is more emotionally attuned to women and children (Wilcox 2004) and able to accommodate women's careers and decision-making responsibilities (Denton 2004; Edgell 2006; Irby 2014). Evangelical scripts of women's submission may increasingly play a symbolic role because of economic pressures that necessitate two incomes (Gallagher and Smith 1999; Gallagher 2003). Similarly, Edgell (2006) argues that Evangelicals respond to gender egalitarianism by emphasizing mutuality within the household while also symbolically affirming male headship.

Scholarship on gender and religion has also fruitfully engaged with the sociology of gender and feminist theory to better understand the workings of gender in religious families. Bartkowski (2001) observes a "tandem negotiation of gender" in Evangelical couples, in which people creatively draw on resources from the Evangelical cultural repertoire to address their family needs. Contemporary Evangelicalism includes debates over wifely versus mutual submission. Spouses grapple both individually and together to interpret, adapt, and occasionally reject such religious discourses. Bartkowski found that most respondents emphasized scripts of wifely submission and men's household leadership, with women talking about their choice to submit (often framed in terms of helping their husbands), while husbands emphasized the commandment to love their wives. Yet couples also told stories of compromise and negotiation, 
illustrating how gender practices often do not match gender ideals. Bartkowski proposes that "wifely submission in word ultimately gives way to mutual submission in deed" (135).

Such scholarship has been important for showing how conservative religions are complex and flexible, adapted by adherents including women for their own purposes (Bartkowski and Read 2003; Burke 2012). Traditionalist gender discourses can be a crucial part of negotiating modern lifestyles and relationship dynamics. Intimate relationships among religious believers are sites of active negotiation, and in some cases religious gender ideals may be more of a symbolic commitment than a blueprint for daily life.

Crucial to my focus on gender negotiations among Muslim married couples are two further insights from recent studies of religion. First, many believers seek to adhere to religious discourses as part of their commitment to religion. That is, rather than trying to circumvent religious restrictions, people may strive to comply with them (Mahmood 2005; Irby 2014b; Avishai 2008). Such a sincere commitment is not incompatible with strategic or critical uses of religion (Author 2015). But from this perspective, elite religious discourses matter because many believers seek to live up to their expectations (Mahmood 113).

Second, just as gender is something that people work to achieve and "do" through daily interactions (West and Zimmerman 1987), so too is religion (Mahmood 2005; Avishai 2008). Mahmood showed that Egyptian Muslim women adopt veiling not simply to express piety, but to cultivate it in themselves. Moreover, people do religion in gendered ways (Irby 2014a; Rao 2015; Darwin 2018). Rao (2015) shows in her study of Muslim converts how the effort to comply with religious expectations makes different demands on men and women. She argues that "doing religion" is guided by gendered religious scripts, and thus, the production of a moral 
religious self is necessarily the production of a gendered moral self (432). I use this concept of gendered religious scripts to describe narratives about gender that draw on religious discourses.

The inextricability of gender and religion can also be seen when religious practitioners appropriate the practices of the other gender in order to redo religious gender norms. Jewish women who adopt the masculine kippot find that their legitimacy as both women and Jews comes in to question (Darwin 2018). Darwin argues: "One cannot simply 'do religion' if that religion holds one gender accountable to a different set of practices than the other gender" (366367). This is especially so in religions such as Evangelicalism or Islam that include strong recommendations about how men and women should present themselves and relate to each other.

Despite the insights of this literature about religion, gender, and relationship dynamics, few recent studies investigate qualitatively the links between gender and religion within couples. Moreover, little research exists on such issues among Muslim couples. This study therefore examines how the gender discourses promulgated through Muslim family law compare to the lived realities of gender among Indonesian Muslims. It does so with a unique focus on the tandem negotiation of gender, especially the use of religious gender scripts among married Muslim couples. How exactly should we understand gendered religious scripts about Muslim women's obedience and men's authority? And what does this tell us about the negotiation of gender in contemporary Muslim couples? I extend the scholarship on religion and gender by showing that Muslim couples' scripts of wives' obedience and husbands' household authority work to accomplish gender as well as achieve status as Muslims. The use of these gendered religious scripts compensates for social changes that put men's authority at risk, and that the ways men and women talk about their marriages and households are not simply repetitions of elite discourses, but mechanisms for accomplishing modern Muslim gender identities. 


\section{THE INDONESIAN CONTEXT: ISLAM, FAMILY LAW, AND GENDER}

Before turning to my research methods and findings, it is necessary to discuss the significant role of Muslim family law as well as recent shifts in gender and Islam in Indonesia.

Nearly $90 \%$ of Indonesia's population of 266 million is Muslim, making it the largest Muslim population in the world and the largest Muslim majority democracy. Muslim beliefs and practices vary widely in Indonesia. While Indonesia has been heralded as more gender egalitarian than other majority Muslim societies, scholars of the region have shown that colonialism and monotheistic religions brought a gender binary structure to Southeast Asia that undermined older traditions of gender fluidity and pluralism (Peletz 2009). Scholars have also documented how the authoritarian Suharto regime (1966-1998) circumscribed women's roles in public life. The regime drew on Javanese cultural traditions and used state programs to instill ideas about women's primary roles as mothers and wives. Since the 1990s, Indonesia has been home to a vibrant women's rights movement that includes both secular and religious activists (Author 2013). But scholars have also chronicled how Suharto era gender ideologies gained a strong hold within the middle class and remain influential in the post-democratization era.

(Sullivan 1994; Brenner 1998; Robinson 2008; Tickamyer and Kusujiarti 2013).

\section{Indonesian Muslim Family Law}

Like many majority Muslim countries, Indonesia has a secular court system and a religious (Islamic) court system, both of which are under the jurisdiction of the Supreme Court. The religious courts deal exclusively with family law and inheritance. In many Muslim settings, Muslims are governed by family laws that are influenced by Islamic law (Esposito and DeLongBas 2001). In most versions of Muslim family law, husbands are envisioned as breadwinners, 
while wives are tasked with managing the household and caring for children. In this complementarian vision of marriage, wives are not usually prevented from working outside the household or earning income, although they may need to seek their husbands' permission to do so. Husbands are obligated to pay for the wife's food, clothing and shelter (referred to as maintenance - nafaqa in Arabic and nafkah in Indonesian), while in return wives are obligated to obey their husbands (Welchman 2011). Wives who fail to do so are considered nushuz (Arabicdisobedient). According to historians, Islamic courts have enforced nafaqaa much more than nushuz, but the concept of nushuz does encode women's submission in marriage (Tucker 2008).

This is justified with reference to the Qur'anic verse from Surah An-Nisa (4:34), which reads: "Men are in charge of women by [right of] what Allah has given one over another and what they spend [for maintenance] from their wealth. So righteous women are devoutly obedient, guarding in [the husband's] absence what Allah would have them guard. But those [wives] from whom you fear arrogance - [first] advise them; [then if they persist] forsake them in bed; and [finally] strike them. But if they obey you [once more], seek no means against them" (Quran.com). Although there are different interpretations, this verse is also commonly used as justification for men's authority over women more generally (Mir-Hosseini 2015).

The gender and marriage discourses encoded in Muslim family laws are influential for many Muslims, even in contexts where they are not governed by them. They have always been subject to interpretation and adaptation, and Indonesian traditions of Muslim family law have historically been more liberal than elsewhere (Esposito and DeLong Bas 2001; Predelli 2004; Read and Bartkowski 2003; Welchman 2011; Van Huis 2015; Nyhagen and Halsaa 2016). Muslim family laws have been the subject of much contestation among Muslims, with some activists arguing for broader implementation or stricter interpretations of Muslim family codes, 
while others strive to shift family law in a more egalitarian direction. Muslim feminists, for example, argue that Islamic law can be interpreted in ways that support gender equality. Their efforts at reinterpretation especially challenge the idea of men's authority or guardianship over women (Mir-Hosseini 2015). Both of these trends are evident in Indonesia, where the bureaucratic institutionalization of Muslim family law has occurred quite recently.

Marriage in Indonesia is regulated by the 1974 Marriage Law, which was the first national law to govern marriage and divorce (Cammack, Young, and Heaton 1996). The law is contradictory when it comes to women's status. Chapter Six, "The Rights and Obligations of Couples," states in paragraph 31 "The rights and position of the wife are equal with the rights and position of the husband both in family life and in society." However, paragraph 31 continues: "The husband is the head of the family and the wife is the mother of the household." Paragraph 33 states that "The husband and wife are obligated to love each other, respect each other, be faithful and give each other spiritual support." Paragraph 34 sets out their duties. "The husband is obligated to protect his wife and give her whatever she needs for their household life to the best of his abilities. The wife shall manage the household to the best of her abilities. If the husband or wife neglects his or her responsibilities, the other party can launch a complaint to the court." (Author's translation, Bahan Penyuluhan Hukum 2001: 124). As is evident from these sentences, the 1974 law does not include many explicit religious references. However, many Indonesians consider the 1974 law to be inspired by Surah An-Nisa because it asserts that the husband is the primary authority in the household (Cammack, Bedner, and Van Huis 2015).

In 1989, the Suharto government strengthened the religious court system, giving religious courts autonomy and full jurisdiction over Muslim marriages and divorces (Feener and Cammack 2015). ${ }^{\mathrm{i}}$ The government released the Compilation of Islamic Law in 1991, a state 
sanctioned version of Islamic law that applies to Muslim marriages and divorces. While the 1974 Marriage Law is still the national family law, the Compilation applies to all Muslim families. ${ }^{\text {ii }}$

The Compilation is intended to be compatible with the 1974 Marriage Law and it gives women more rights than many other versions of Muslim family law (Nurlaelawati 2010; Cammack, Bedner and Van Huis 2015; Van Huis 2015). For example, wives have broad grounds for divorce and custody of children. However, like the 1974 Marriage Law its messages about gender are contradictory. For example, Paragraphs 80 and 83 set out the obligations of husbands and wives. Paragraph 80 states: "The husband is the leader (pembimbing) of the wife and the household, however important household business will be decided by the couple together." It goes on to stipulate that "The husband protects his wife and provides her daily needs to the best of his abilities" and depending on his earnings, he is required to financially maintain the household (using the word nafkah), pay for medical care for his wife and children, and pay for the children's education (paragraph 80). This paragraph also states that the wife can free her husband from the obligation to provide a living for the household and pay for medical care. Paragraph 83 on the obligations of the wife reads: "The primary obligation of a wife is to be pious and devoted to her husband within the bounds of Islamic law" and "The wife must maintain and manage the daily needs of the household as best she can." Paragraph 84 notes: "The wife can be considered nusyuz (disobedient) if she does not carry out her obligations as specified in paragraph 83 unless there is a valid excuse." It continues: "As long as the wife is nusyuz, the obligations of the husband to his wife as stipulated in paragraph 80 are not valid except for important issues relating to the children" (Author's translations, Bahan Penyuluhan Hukum 2001: 182-183). 
The Compilation represents a more explicitly Muslim articulation of gender relations in the household than the 1974 Marriage Law. The use of the words nafkah and nusyuz and the stipulations about husbands' and wives' obligations are direct references to Islamic law (Tucker 2008). While it is more liberal than the family laws of many Middle Eastern countries, it does not reflect the egalitarian Islamic interpretations of Muslim reformists (Welchman 2011). And the Compilation is increasingly influential as more Indonesian marriages and divorces are formalized through the religious courts (Nurlaelawati 2013). ${ }^{\text {iii }}$ Finally, because of its institutionalization as state law it is an authoritative vision of gender relations.

\section{Changes in Indonesian Muslim Family Law}

What has driven the shift to a more explicitly Muslim family law? An Islamic revival since the late 1980s along with democratization after 1998 have resulted in substantial changes in religious and political life. Crucial to the Islamic revival in Indonesia and elsewhere is the idea of piety. To be a good Muslim in the contemporary world is to adopt orthodox pious practices, especially those that are visible and public, such as veiling for women, observing taboos on alcohol, and more (Mahmood 2005). As Brenner observes about the Islamic revival in Indonesia: "This movement has had rippling effects in virtually all spheres of social and political life, as seen in the changing modes of piety, ethical decorum, modes of interaction, and styles of dress; in the introduction of Islamic law into local and provincial legal codes; and in the rise of both religious extremism... and mainstream Islamic consumer culture" (2011: 478). In this context, to become a good Muslim in Indonesia is to adopt more publicly pious practices. Arguably, in this era, the state both increasingly recognizes religious authority in its family law efforts as well as seeks more control over the interpretation of Islam (Feener and Cammack 2012; Menchik 2016) 
Such changes have not necessarily disempowered women. Indonesian women's rights activists synthesize Islam and feminism in creative ways to argue for gender equality (Blackburn 2004; Robinson 2008; Brenner 2011; Rinaldo 2013). For example, they argue that the obedience in Islam means obedience to Allah, not husbands. Such activists provide an alternative and egalitarian set of Islamic gender ideals. Their arguments have helped to pass legislation such as the 2004 Anti-Domestic Violence Law and have also underpinned recent reforms that have made religious courts more responsive to women. Their ideas are a potential source of leverage for women negotiating ordinary household life.

These religious changes have occurred amidst other social changes. Indonesian women, especially those in the middle class, have increasing work and educational opportunities. Indonesian women have long worked outside the house, but mostly in the informal and agricultural sectors. Indonesian women's labor force participation rose from $26 \%$ to $51.4 \%$ between 1971 and 2014, though it has not changed much since 1990 (Schaner and Das 2016). Research shows that educated young women do not plan to give up their careers after marriage (Utomo 2015; 2016). Women are gravitating toward the service sector, with 58\% of working women in non-agricultural sectors (Schaner and Das 2016). In 2016, just 12\% of Indonesians aged 25-34 had tertiary education, but the percentage of women among those enrolled in tertiary education rose from $9 \%$ in 1990 to $32 \%$ in 2012 (OECD 2016). The country's gender parity index (GPI) for secondary education improved from 0.53 in 1970 to 1 in 2015, meaning that the ratio of girls to boys in secondary education is now the same (Lowy Institute 2018).

Ideas about women's lesser status and men's authority are certainly not new in Indonesia and Suharto state discourses about women's domesticity certainly played a major role in legitimizing such ideas. Yet the words obedience (taat) or disobedience (nusyuz) with regards to 
wives are not notable in major ethnographies of gender in Java from the 1980s and 1990s (Sullivan 1994), (Brenner 1998), (Tickamyer and Kusujiarti 2012). However, in her study of divorce, O'Shaughnessy (2009) sees an increasing tendency for religious courts after 2000 to emphasize wives' obedience (199) and this was also a prominent theme in my interviews. This most likely is influenced by the use of the term nusyuz in the Compilation of Islamic Law. It suggests that Islam has increasingly become the language used to justify gender hierarchies.

Overall in Indonesia, a particular version of Islamic family law is more institutionalized in the state and influential in everyday life. It envisions women as primarily domestic and men as breadwinners and it provides men with authority over the household. On the other hand, the increasing educational attainment of Indonesian women, especially in the middle class, means that they have a broader array of work opportunities, as well as access to better paying jobs that pose a challenge to the male breadwinner ideal. These dynamics make Indonesia an especially significant context to examine the intertwining of gender and religion among Muslim couples.

\section{METHODS}

This article draws on interviews and fieldwork with Muslim married couples in Malang, East Java, Indonesia in 2013. Malang is a city of 820,000 . As elsewhere in Java, about $90 \%$ of residents are Muslim (BPS Malang).

Malang is often referred to as "kota pelajar" (city of students) because of its universities. At last count, the city has at least 17 institutions of tertiary education, including a state university and a state Islamic university, as well as numerous private institutions of higher education.

The full study included 34 Muslims, 5 Protestants, and 2 Catholics (total $=41$ ). This article is based on the interviews with 18 Muslim women and 16 Muslim men. This group of 34 
consisted of 16 married couples, one widow, and one wife whose husband declined to be interviewed. The ages of the Muslim participants ranged from age 26 to 70 . There were 16 Muslim participants in their 20s and 30s, 9 in their 40s, 7 in their 50s, and 2 over 60. Most couples were close in age. Sampling was a combination of purposive and snowball. I worked with one male and one female research assistant, both recent graduates from a local university. For convenience, I focused on a walkable area of the city.

Although some participants had difficulty estimating their monthly household incomes, the reported estimates ranged from as little as 200,000 rupiah (a little over \$20) to a high of about 22 million (\$2500), with about three quarters of respondents reporting between 1 and 5 million rupiah per month. (The Boston Consulting Group defines middle class in Indonesia as ranging in purchasing power from 1.5 million to 5 million rupiah per month, accounting for about 141 million people [2013]). This study therefore does not include many households at the extremes of poverty and wealth, but it does capture the increasingly broad middle.

Nine of the 18 Muslim women interviewees worked outside the house. Many were employed as teachers and a few worked in the private sector. Of the women who did not work outside the house, some had a home-based small business, and/or managed rooms for student boarders. Men worked as teachers, government employees, and small business owners.

My interview participants were more educated than average. Fourteen of my 34 Muslim participants ( 8 women and 6 men) had at least some tertiary education (41\%). However, 20 Muslim participants had a high school education or less, with 5 having only an elementary school education. It is important to note that in Indonesia and other Muslim contexts, conservative and textualist understandings of Islam are especially strong among the educated urban middle class (Mahmood 2005; Sidel 2006; Brenner 2011). 
I interviewed individuals inside their houses. Husbands and wives were interviewed separately. Interviews were semi-structured and included questions about gender, the household division of labor, and religious attitudes. Interviews were conducted in Indonesian, the national language. The research assistants did not translate, but occasionally asked "probe" questions.

I initially used MS Excel to sort respondents based on age, gender, educational levels, religion, and income. After doing open coding of the interview transcripts by hand, women's obedience and men's authority emerged as the most prevalent themes. I used NVIVO to code interviews for these and related themes such as authority, leader, and respect.

There are certainly limitations to this study. First, this is a small sample. However, the goal of a qualitative study such as this is not to be representative but to achieve saturation of diverse perspectives (Small 2009) and I think my sample achieves this goal. Second is my presence as a white American woman. I have done extensive fieldwork in Indonesia and speak the language. I did not find that being a woman made it difficult to talk to men, perhaps due to the research assistants. My presence probably made the interviews more formal and may have encouraged people to explain their religious beliefs and to present themselves as "good" Muslims. However, the fact that my presence may have elicited certain scripts allows for an analysis of those scripts and why people aimed to present themselves in certain ways.

\section{GENDERED RELIGIOUS SCRIPTS: OBEDIENCE AND AUTHORITY}

The neighborhoods where I conducted interviews included a dense mix of housing ranging from tiny concrete houses in alleys too narrow for cars to spacious McMansions on tree lined streets. Most houses are one or two stories, but second floor windows often have views of the mountains, including a smoking volcano. During the day there are vendors roaming the streets with carts, 
housewives hanging laundry, food stalls catering to students, and grandmothers or maids caring for young children. As the universities have grown, many houses have added rooms for boarding students. At any time of day, there are students traveling through the neighborhood on foot or by motorbike. During the week, many Indonesian urban neighborhoods are dominated by women and children and the elderly, with adult men (and some women) away at work. In this case, the additional element of students means that neighborhood almost always feels active and busy. My interview questions about gender in the household tended to prompt scripts about wives obeying their husbands and husbands' authority over the family. Eighteen of the 34 Muslim interviewees told me explicitly that men are heads of the household, and it was clear from nearly all research participants that they would agree with this statement. Eleven out of 18 women and four out of 16 men said that wives should obey their husbands. Such answers came in response to interview questions about the differences between men and women, the household division of labor, or what makes a person a good Muslim man or women. Much of the time, these statements were justified with reference to Islam. Yet most interviewees did not refer specifically to religious texts. Instead, their answers were more general, along the lines of "In Islam, wives are supposed to obey their husbands." Such generality leaves open the possibility for multiple meanings, such as wives are supposed to obey but don't necessarily do so, or wives are supposed to obey husbands in certain contexts.

Women expressed the idea of obedience in several ways. More so than men, many women spoke about it directly, using the words taat sama/pada suami (to obey the husband). A young woman said, "You know, women must obey (taat) their husbands, they shouldn't be above their husbands," and when I followed up by asking whether she thought men and women were naturally different, she replied, "In religion and in kodrat (a Javanese term meaning a 
person's essential gendered nature) women must serve (melayani) their husbands." Others chose different words. As one middle-aged woman said: “A good Muslim wife doesn’t reject any requests, her husband is the head of the household, so she should talk politely to her husband." Some women used the phrase harus mengikuti suaminya - women must follow their husbands. A few used the word patuh rather than taat- this word is more ambiguous, as it can be used to mean loyalty, but also is widely used to mean obedience. Finally, a few women did not use taat or patuh but said that wives should respect (menghormati) their husbands.

Men used the word obedience (usually using the word taat) less often than women, although it was clear that most of them agreed with the idea of wifely obedience. Similar to the Compilation of Islamic Law, men talked about their responsibilities as being a household leader, provider/protector, and/or a moral guide for their family. For example, when I asked him about his duties in the household, a middle aged man told me, "Well, I'm the head of the household." When asked to be more specific, he said, "I am responsible for the children's education." Later, he said that a good Muslim husband is one who "leads his wife and children well." A very common statement from men was that voiced by a 37 year old man who said: "My religion says that men should be leaders in the household." A few men forbade their wives from working while their children were young. As I will discuss later, a small number of men emphasized mutual respect (saling menghormati) or cooperation between spouses.

Certainly, women were more likely to use the word obedience because in the Compilation of Islamic Law it is associated with their role in the marriage, while the script of household authority was more pronounced among men because the Law associates it with their role in the marriage. However, the use of the word obedience and the emphasis on male headship was more evident among interviewees under 50. For example, of the 11 women who used the 
term obedience explicitly, 10 were under 50, seven worked outside the house, and five had at least some university education.

My interviews with Arief and Putri demonstrate the typical ways couples voiced these scripts. Arief is 50, with a high school education. He runs an internet café out of his house. His wife Putri, also a high school graduate, is 47 . She works out of the house as a tailor. They have two children, one of whom is in college, but their finances are shaky. She earns about 700,000 rupiah per month, while he earns about 1 million a month, making a total of about $\$ 200$, or just barely lower middle class. During university breaks, students return home, so Arief's income drops considerably. They admitted that their income is sometimes barely enough to cover basic expenses and they rely on assistance from their eldest son, who works while he is in school.

Arief agreed that women and men should have the same rights in education and politics. "Yes, it's the same," he told me. "It should be as high as the sky. But still, in the household, it has to be a special rule that a woman is under a man. Other than that, everything is possible. But if we make it the same in the household, there will be no leader and our household will be in danger.... In household life, it's still necessary to keep our rules according to our religion. The mother has to be under the father, the leader is the father." Nevertheless, he also stressed that the family is a team, in which everyone helps each other. He said that he often cleans the house because his wife is busy with her work.

Putri echoed much of what her husband told me. She recognized that the income from her work was critical for the family. When I first asked about the differences and similarities between men and women, Putri said that men are supposed to be heads of households. And then she added somewhat jokingly, "Women should be obedient, ha ha ha, unless they get some ideas. But men and women are equal nowadays." When I pressed her, she said that men are made to be 
leaders, while women are made to be mothers, but she also felt that they should have equal rights in work and education. Many respondents used the words for woman and wife interchangeably, and when I asked Putri what it meant to be a good Muslim woman, she replied that it means being devout in religion and following her religion's rules. When I asked about being a good Muslim wife, she answered, "It's to be obedient to her husband."

These statements reveal themes voiced by many interviewees. The spouses connect their complementarian gender ideology to Islam. Yet while Arief is often the breadwinner, Putri's income is significant and more stable. He does not challenge her working and earning incomethis is taken for granted.

Although she bears the burden of domestic responsibilities, he is proud to say that he contributes to certain household tasks. However, this is framed as something he does to be helpful, not as a necessary part of being a husband. What is connected to his role as husband is authority over the family. Similarly, she is pleased for women to have equal rights in work and education but expresses her view that to be a good Muslim wife is to obey her husband. Thus, Arief and Putri suggest that women's obedience to men is expected in the household, but not in public life, a leitmotif that emerged in many interviews.

The script of obedience is a way for women to achieve being pious and "good" Muslim wives. In an era of Islamic revival, this also helps to reconcile potential contradictions between the family ideals of Muslim family law and women's needs or desires to take advantage of education and work opportunities. The obedience script also bolsters Arief's manhood at a time when his breadwinner status is at risk. And his talk about his household authority thus becomes a way to accomplish his status as a Muslim husband. 
Some couples emphasized the script of wives' obedience very explicitly, while others placed more emphasis on the script of husbands' household authority. In the following sections, I discuss how each of these scripts and how they were used, and I also show how the dynamics of gender and religion revealed in interviews were evident in local institutions.

\section{THE SCRIPT OF WIFELY OBEDIENCE: ACHIEVING MUSLIM WOMANHOOD AND BOLSTERING MUSLIM MANHOOD}

One of the youngest couples I met was Toni, 27, a salesman and high school graduate, and Dian, 26, also a high school graduate. They had one young child and Dian was pregnant with another. They lived in Dian's mother's house and their income was about two million rupiah per month, a little under \$200. Toni said that men and women should have equal rights, but that men should be leaders. When asked to specify this, he said with conviction that men should be the breadwinners. When I asked how he would feel if his wife wanted to get a job he replied: "To me it's fine, but it depends on the husband. Women aren't allowed to disobey their husbands' orders. Our religion tells women to stay in the house taking care of the family, but it's okay for women to work if they really need to help with the finances." When I asked him what it meant to be a good Muslim man, he answered, "A Muslim man should guide his children and his wife, men are responsible for everything in Islam.”

Dian worked before she had children, and she seemed to think it was a good thing that women could get education and become leaders. She viewed the household and childcare as her responsibility, though she said that she and Toni discussed everything. Although she described herself as not very devout, she said that she thought religion was crucial for her children and wanted to send her daughter to a Muslim boarding school so that she would learn Islam properly. 
When I asked her how Islam affected her role as a wife, she said, "It has a lot of influence because it teaches me to obey my husband." Later, when I asked her what it meant to be a good Muslim woman, she answered immediately: "To be obedient to my husband, devout in religion, like in the Islamic books. Islamic books teach us to be obedient to our husbands."

Andi and Dian are not trying to adapt elite religious gender discourses but seeking to comply with them. They are eager to achieve their statuses as Muslim husband and wife through their religious gender scripts. Although Andi's breadwinner role does not seem to be at risk, they both seem to recognize that men's breadwinner status more generally is at risk in this context. Dian's answer about what it means to be a good Muslim woman is not just about her achievement of gender, but also safeguards her husband's manhood. Andi does not necessarily oppose the idea of Dian working outside the house, but it has to happen with his permission. This ensures that even if she takes on responsibilities that challenge their division of labor, the way they talk about his authority does not change, protecting his Muslim manhood. Notably, his view on this is more conservative than the Compilation of Islamic Law, which does not say that wives need to ask their husbands' permission to work. Although they were interviewed separately, their accounts jibe with each other, demonstrating the relationality of gender (Bartkowski 2001).

The script of women's obedience may take on greater importance when the wife earns significant income. Fajar Halim, 43 and his wife Siti, 35, are one of the most affluent couples I encountered. They live in a spacious house on a street that has many large houses to which the owners have built additions for boarding students. Fajar is an independent building contractor, so his income varies, but he said it was generally between 5-10 million rupiah per month, though that also includes income from the family's boarding house business, which is mostly overseen by Siti. Siti earns 5 million a month from her job as a marketing manager for a hotel, and she is 
also an investor in a small business which brings her another 6 million per month in additional income (for a total of about 20 million rupiah per month - about $\$ 2000$ at the time I conducted the research, putting them in the upper stretches of the middle class). Both are college graduates, but Siti has a master's degree. They have two young children.

Plainspoken, Fajar was happy to discuss his views on religion and gender. 'I'm a Muslim, so the differences between men and women are that men are supposed to work outside while women are supposed to take care of the children." When I asked if men and women should have equal rights, he said, "I think they do, as long as they are qualified enough to become a leader, why not?" On the other hand, he repeated, "Based on religious rules, women are supposed to stay at home and mind their children."

However, Siti works full time. Fajar said that he washes the car and the motorcycle and takes the trash out, as these are "masculine duties." Siti cooks, takes care of the children, and prepares breakfast. He said they both clean the house. Unlike many other affluent families, they did not have a regular maid. Fajar seemed conflicted about his wife's work. In fact, in her previous job, he was unhappy about her long hours, and insisted that she quit.

When I interviewed Siti, she seemed exasperated with Fajar's failure to help around the house. During the interview, which took place in the evening, the two children frequently interrupted us, wanting someone to play with them. Fajar stayed in the back of the house watching TV and reading the newspaper. I felt that he was intentionally performing what he considered to be the proper gender division of labor in the home. And as his interview reveals, this division of labor was closely connected to Fajar's religious views.

Fajar said that Islam was very important in his life. In his view, a good Muslim husband is a leader in the household and a good Muslim wife obeys him. "A man should be responsive to 
his wife and children. And especially to his God, though it's enough to protect the family. But so far, I still let my wife work. I told her that even though she has like 500 subordinates she still has to obey me. I'm afraid that sometimes successful wives disobey their husbands. It happened to my colleague. She doesn't want to get married because she's afraid that the man would limit her. She's 40 now and hasn't married because she's afraid of the limitations." When I asked what he thought about that, he said, "It's her choice, but for me the ideal is to marry, and she may work and also be responsible for her family. If she doesn't marry or chooses to divorce and prioritize her career, that's her right, but it's not how we create partnership."

Siti attributed their differences to divergent backgrounds. She told me that in Fajar's affluent but religiously conservative family, women stayed home, despite having good educations. In contrast, her family was lower middle class and her parents had a troubled marriage, but they raised her to be independent. "My husband thinks that is better for a woman to stay at home, while I think it's a shame since I have an education... Perhaps he embraces his family's culture and he thinks that the boarding house business is sufficient," she remarked.

She was vocal about the dilemmas of "career women" like herself. "Sometimes a woman needs to reconsider if she's being promoted to a higher career level. In my job, I would take a higher position if I am still able to look after my children. Every career woman feels the same. Husbands usually think that it's better for a woman to stay home." In fact, she continued, in her last job she was offered a promotion, but Fajar tore up the papers when she told him. "I tried and tried to tell him that I work for our family. We dream to have our children study abroad and so we have to start saving and investing. He supports me now," she said. After he forced her to resign, she complained so much about being at home that he encouraged her to find a new job. 
I asked Siti if she thought women should stay at home. Siti declared that such a thing is "old people's doctrine" and that men and women should have the same opportunities. However, she said, she would resign if her husband had a higher and more consistent income.

Siti also said that a good Muslim wife is obedient to her husband: "A good Muslim wife is an obedient wife and sets many good examples for her children." She veiled while in college at an Islamic university, then stopped veiling in her 20s but began again after going on the hajj and in response to Fajar's request. But she also expressed dissatisfaction with their division of labor. "I have a larger portion of the duties here. I still have to handle the children after I get back from work since my husband isn't able to. Actually, I want him to be able to deal with the kids too." She said that Fajar also made most of the major decisions. "He'll make his own choice even if he asks for my opinion. It's fine, I respect my leader, ha ha ha." Like many Javanese women, she manages her own income, which she says is for the children and future investments. ${ }^{\text {iv }}$

Siti seemed to be struggling to reconcile her belief that women should be able to have careers with her marriage to Fajar, who was willing to let her work because of the income but would do little to ease her domestic burdens. Even though she was contributing at least half of the family's income, she was unable to get Fajar to take on more household responsibilities. Despite her pride in her career, she emphatically agreed she was willing to obey Fajar, even if it meant giving up her job. Nevertheless, Siti worked long hours. I was staying across the street, and often observed them returning home from picking her up at work around $8 \mathrm{pm}$.

Siti's use of the obedience script signals that she is ready to fulfill what she sees as her domestic responsibilities, which in her understanding are crucial to be a good wife. While Fajar recognizes the importance of her income, her emphasis on obedience also helps to underplay her income earning, high status career, and long working hours. Such deference may make Fajar less 
concerned about her work outside the house. Yet while this private-public division gives Siti more freedom to pursue her career, it also gives Siti the burden of domestic responsibilities.

Siti's adherence to the obedience script means that she is not simply a good wife, but a pious Muslim. She is clearly striving to be a good Muslim wife and the obedience script is the way to accomplish this. Moreover, her obedience script bolsters Fajar's authority as a Muslim man, especially given that his breadwinner status is very much at risk in this marriage. Indeed, Fajar's remark about his wife still needing to obey him even if she has 500 subordinates suggests a need to reinforce his sense of masculinity, which is inspired by a particular understanding of Islamic gender ideals. It is not her working per se that is the problem, as this has long been the norm in much of Indonesia and is allowed in most versions of Islam, but it is her career ambitions and success in the workplace that could upend the hierarchy in the household.

In both of these cases, women's narratives that revolve around wifely obedience are not just about achieving Muslim womanhood, but also safeguarding their husbands' Muslim manhood. As the example of Siti and Fajar suggests, I found that the couples in which both partners most emphasized scripts about wives' obedience and husbands' authority tended to be under 50 and/or included a wife with significant income. As mentioned previously, the script of obedience was more common among younger women who worked outside the house (seven of nine Muslim women, two of whom were close to being breadwinners). The small size of this sample makes it difficult to draw conclusions about this pattern. However, it is suggestive of a pattern noted by scholars of religion and gender, in which people compensate ideologically for their deviation from expectations. For example, Gallagher and Smith (1999) find that American evangelical couples adhere to ideals of male authority and female submission even while both partners are working and dividing up the household labor. They argue that such "symbolic 
traditionalism" provides a way for Evangelicals to maintain a sense of cultural distinctiveness, although the reality of their lives is better characterized by "pragmatic egalitarianism."

In this case, cultural distinctiveness is not the major concern, but there seems to be a similar process operating, in which wives who work outside the house, especially if they earn significant income, shore up conventional hierarchies by emphasizing their obedience and their

husbands' authority. These women are also invested in such hierarchies, as they seek to be good Muslims. Similar to what Macleod (1992) argues in her study of the resurgence of veiling in Egypt, presenting herself as a pious Muslim gives Siti greater license for her work outside the house. Yet while Macleod emphasizes the potentially problematic aspects of Egyptian women entering masculinized public spaces, the couples discussed here appear to be more preoccupied with gender relations inside the household. As public life becomes more egalitarian in Indonesia, it is domestic life that becomes the focus of efforts to (re)establish traditional gender norms.

This theme can also be seen among the smaller number of couples who tended to express their adherence to Muslim family law through discussions of husband's household authority.

\section{THE SCRIPT OF HUSBANDS' HOUSEHOLD AUTHORITY: ACHIEVING MUSLIM}

\section{MANHOOD IN A CHANGING SOCIETY}

Abdul is 38 and works in his family's shop and sells street food, despite having a bachelor's degree. He was the neighborhood head at the time of my research. His wife Fitri, 35, also has a bachelor's degree and is a public school teacher. Because of his position, they were well known in the community. They have one child and earn about 3.5 million (about \$400) per month. Though his income was usually higher, her job came with benefits and was more stable. 
Abdul at first told me that there aren't many differences between men and women. $\mathrm{He}$ said that he thought that women should be able to be involved in politics or have jobs, and at the end of the interview he said that one of the big changes in the neighborhood in the last twenty years is that there are more working women, and more occupations that women can enter. He said that he and his wife help each other at home, and he said that often takes care of their son.

However, Abdul stressed that that supporting the family is the husband's responsibility in Islam. He said that Fitri had to ask his permission to take a job. "I have to be familiar with her working environment," he said, "I allow her to be a teacher, but it's important for me to be familiar with her environment so that we have mutual trust."

For Abdul, the household seems to be a different realm than the public, one where religion plays a stronger role. "Islam influences my daily life, it's unstoppable," he said. "There are rules that husbands should reprimand their wives, and we should follow the rules." Yet clearly, Abdul like others saw this as compatible with women working outside the household.

Fitri was more explicit about the difference between public and private life. She told me, "Nowadays there are no significant differences [between men and women], as women can also lead. Men have to lead the household well." As the wife of the neighborhood head, Fitri also led the neighborhood branch of the state women's organization, and she was known and respected in the area. She went on to tell me that men and women should have equal rights to education and that women can have the same abilities as men, but that wives must obey their husbands at home. When I asked her to elaborate, she explained, "Our religion has arranged the rights and responsibilities between men and women. We have to fully understand such limits in accordance with Islamic life guidance. As wives, we should respect our husbands, and our husbands should adhere firmly to religion, and so we have to remind each other of this." 
In fact, when I asked Fitri about the division of labor in the household, and how her husband felt about her both working and being a community leader, Fitri told me: My husband allows me to be active in the organization as long as I can take care of my family. I will cook if I have the time, otherwise I'll just grab takeout.... He understands because his mother was active in the organization as well. I was also previously the secretary of Muslimat [a local branch of a national Muslim women's organization]."

Fitri demonstrates her Muslim womanhood through her compliance to the norms of Muslim family law, but her language about this is somewhat muted. She emphasizes the script of husband's leadership more than the script of obedience. Abdul supports her work, while also being clear about his authority in the household. While Abdul is willing to do some child care, the home is Fitri's responsibility. As previously mentioned, - in the case of Fitri and Abdul, the scripts of wives' obedience and husbands' authority apply primarily to the domestic sphere.

For another more affluent couple, the obedience script was also lower key, but the script of husband's authority in the household was still strong. Halim, 37, has a master's degree, is working on a doctorate, and is a lecturer (similar to assistant professor), and Nadirah, 32, is a college educated housewife who worked before she was married. They lived in a nicely furnished house on a street lined with deluxe student boarding houses - indeed their boarding house was one of the more prominent in the area. Even with the income from the boarding house, it was not obvious to me how Halim's income from university teaching supported their affluent lifestyle, but a neighbor told me Halim had inherited the property from his parents.

Halim made many of the same distinctions as other respondents, explaining that in Islam men are supposed to lead households, though he qualified this by saying that his wife and children were supposed to have input. "In our culture, men are supposed to lead the household. 
I'm a Muslim and Islam teaches men to lead. However, my wife would complain to me if I did something wrong. It doesn't mean I can't hear a complaint just because I'm a leader, both my wife and my child complain to me. They often criticize my rubber time behavior."

He expressed openness to women's involvement in public life, saying that some women are smarter than men. When I asked how he would feel about Nadirah working, he responded, "It's up to her. I would let her, but I'd give certain preconditions. I'd let her work if there is someone able to look after our children. She actually has gotten many job offers. It's fine for her to work in social or commercial activities. She used to supply building materials, and that was fine because she just needed to make a call."

Nadirah explained to me that she and Halim cooperate in everything - for her, this means he works while she takes care of the children "Sometimes it's better to work, but I prioritize my children," she said. She referred to caring for her children as "my job." When I asked her if she thought wives should stay home, she responded, "It was hard to accept the truth at first. Because I went to college, my parents wanted me to work in a bank or to be a secretary. It was just a plan. I had children after I married, so then who would take care of them? I couldn't have them taken care by the babysitter, that would be such a shame. I took care of them myself, I had to make sacrifices." Yet when I asked her more generally if women should have the same rights as men to get an education or a job, she said adamantly, "Oh, of course yes... Why not, women should be able to do so." In fact, she said she may return to work when the children are older. Thinking realistically about her chances of reentering the labor market, she said that she would have to do something entrepreneurial, such as a restaurant or a catering business.

Unlike many women I interviewed, Nadirah didn't cite religion as a justification for male authority. Instead, she spoke about being the primary caretaker of the children as her "duty." 
Halim talked about his role as a household leader with mentioning obedience. It's possible that Halim was tailoring his answers for me. But he was a high status person being interviewed in his well-appointed house - I did not sense that he was trying to impress me.

Halim and Nadirah may reflect a trend among upper middle class Muslims to talk about their household in more mutualistic terms, possibly influenced by religious reformists who have argued for more egalitarian gender relations. Higher status people may have less need to demonstrate their adherence to convention. And perhaps because Halim's masculine authority is not at risk in this marriage, they are comfortable with more negotiation. But significantly, even though they downplay the script of wifely obedience, they show a similar dynamic to other couples in their emphasis on the script of husbands' household authority. Halim presents himself as a leader of the family, emphasizing that he would allow Nadirah to work, with certain conditions, mainly that she has a plan for appropriate childcare. Like others, he connects his masculine authority to his religion, saying "Islam teaches men to lead."

These examples demonstrate a pattern of emphasizing the script of husband's authority more than wives' obedience that was more common for younger and well educated couples. Halim and Abdul both are aware that public life has become more egalitarian and do not seem upset by such changes. Yet they too voice the script of husbands' authority, suggesting that this script is still an important way for Muslim men to accomplish gender and religion.

\section{GENDER AND RELIGION IN ACTION}

While interviews are especially useful for eliciting discussions of gender and religion, gender and religion are also of course "done" in less explicit ways. One place to see this is in local institutions that are not overtly religious. 
One of the few formal institutions that brings women together in urban neighborhoods is the PKK - Pembinaan Kesejahteraan Keluarga, or the Family Welfare Program. This organization is a remnant of Suharto era development policies. It was created in the late 1960s to alleviate poverty through nutrition, health, and educational programs targeting women and children, and it originally had branches in every village and neighborhood in the country. Traditionally, the wives of local male bureaucrats are the heads of the local PKK. Scholars have long been critical of how the PKK was used to mobilize support for the regime's goals, as well as of its emphasis on women's domestic roles (Tickamyer and Kusujiarti 2013). Nevertheless, in the post-Suharto era, the PKK has become less politicized and plays an important role in providing women with information about health and nutrition.

In the neighborhood where I was doing my research, the monthly PKK meeting was combined with an arisan. The arisan is a women's savings club, an informal institution that is widespread in Java. A group of women meet monthly and each contributes a fixed amount of cash. They draw numbers and at each meeting a different woman "wins" the whole pot.

I attended a joint PKK/arisan that took place in a house situated in one of the neighborhoods' narrow alleys. About 10 women sat in the alley outside, and another 20 on the floor of the living room, chatting and laughing. Most of the women wore headscarves and tunic blouses with long skirts, but it was clear from their clothes and their teeth that many were lower class. There was a microphone and amplifier, and bowls full of snacks.

Fitri's status as PKK head and wife of the neighborhood head was obvious. She was dressed fashionably according to pious middle class standards, including a long maroon headscarf decorated with tiny beads and a deep purple tunic and skirt, and she had good teeth and 
glowing skin and wore lipstick. She spoke clearly, with an authoritative tone in her voice (using the microphone) and used simple enough words for everyone to understand.

The meeting began with a long discussion of the previous year's financial report. I was told that the PKK meetings in this neighborhood consist mostly of educational programs as well as Quranic study sessions (pengajian) for the women, although neither of those was happening at this meeting. According to the visitor book, the previous outside visitor was a representative from a local organization providing information about cervical cancer screenings.

Once the PKK business was over, the arisan began. For this arisan, each woman contributes 10,000 rupiah per month (a little less than $\$ 1$ at the time). Each month the arisan may collect anywhere from $400,000-800,000$ rupiah, and there are often as many as 50 women participating. Every transaction is carefully recorded. This arisan also operates as a cooperative, and women can borrow from it, or they can use money as a group to undertake various activities.

Finally, it was time for the distribution of money. Things got loud and raucous as women waited for their names to be called and the envelope of cash passed to them. When I asked the woman sitting next to me what most women used their money for, she said school related expenses or paying off bills. As soon as the lucky recipients got their money, they left, and the room cleared out quickly.

Later that evening I attended a men's arisan organized by Abdul, the neighborhood head and husband of Fitri. I had never heard of such a thing, and neither had most people I spoke with, but Abdul told me that he recalled men's arisans in the neighborhood when he was a kid. In any case, he said he had initiated this men's arisan as a form of "gotong royong" or mutual assistance - a longstanding Indonesian concept that was coopted by the Suharto regime to promote a sense of moral obligation to the the state (Bowen 1986). Abdul told me that this arisan 
does not have a pengajian, but he uses the meetings to convey information from the government, such as about the new government e-identity cards, to provide health information, and also to find out about potential problems in the neighborhood.

The men's arisan took place in the same room as the women's arisan. About 20 men of varying age gradually arrived. Most were dressed casually, in jeans or trousers with short sleeved shirts. As with the women, about half sat in a circle on the floor, and others sat in the alley outside. The arisan was led by Abdul and his assistant. They were both in their mid-late 30s, university graduates and their clothing and manners were more polished and prosperous than most of the other men. The arisan meets once a month, and each man contributes 2500 rupiah (less than 25 cents). Sometimes they also organize outings - Abdul said they were planning a trip to the beach next month.

The meeting began with announcements of events, and a discussion of a celebration for an upcoming religious holiday. The problem was that the local mosque council wants each neighborhood to contribute rice and money for the event. Abdul said that he thought it would be too much of a burden for neighborhood residents, as it happens every year. He said he asked if they could contribute cakes/sweets instead, but the mosque council didn't like that idea. So, he complained, they are stuck with having to contribute. This did not arouse any discussion.

Next Abdul initiated the arisan. They rolled dice and one man won the lot. In general, this arisan was shorter and much calmer than the women's arisan, partly because it didn't have as many people. The men chatted quietly (some just smoked and did not speak). They joked around but were not as raucous as the women. It is also possible that my presence as a foreign woman caused them to be quieter than usual. 
The differences between the women's and the men's neighborhood meetings highlighted the dynamics evident in many of my interviews. The women's PKK/arisan reflects the gender negotiations in many marriages. The meeting focuses on family and health issues in ways that do not challenge conventional gender scripts, and it also has a religious component with the regular pengajians. Fitri's leading of the event involves doing Muslim femininity. She takes on a public role, yet she is leading other women rather than men, and does not challenge the conventional norms of authority in Islam. She comports herself in a way that emphasizes her commitment to Muslim piety and also signals her high status. Yet the PKK/arisan also connects women providing them with a space of activity outside their homes, giving them access to financial resources, and linking them to state development goals. In contrast, the men's arisan was struggling to define its role in the neighborhood. It was clear that men wanted to be involved in public leadership, but they seemed unsure of what exactly they wanted to do. Except for Abdul's position as neighborhood head, they lacked a strong connection to public institutions. The amount of money circulating through the arisan was smaller, and it was used for pocket money rather than as a poverty alleviation mechanism. Finally, the men's arisan had no religious component, suggesting that the performance of piety is more important for women. The less focused men's arisan seems to reflect men's struggle to maintain authority at a time when women are becoming more influential in public life.

\section{CONCLUSION}

In contemporary Indonesia, Muslim family law has become increasingly institutionalized and influential. This has happened at a time of rising rates of women's education and diversification of work opportunities for educated women. Greater institutionalization of Muslim family law 
coexists with social changes that potentially challenge the male breadwinner model embedded within the law. How does such a context influence gender negotiation between married spouses? While most studies of religion, gender, and marriage focus on Christians, this article investigates the tandem negotiation of gender among Muslim married couples, showing how gendered religious scripts are crucial to how married Muslim men and women enact gender identities, especially when the conventional gendered order is at risk.

Not only do people often practice religion in gendered ways, they also do gender in religious ways (Avishai 2008; Rao 2015; Darwin 2018). Scripts of wives’ obedience and husbands' household authority are not simply recitations of religion, nor do they usually reflect attempts to grapple with religious gender norms, but rather, they are a way to accomplish both gender and religion. This article highlights how a particular context can amplify this process.

In contemporary Indonesia, gender ideals that stress men's authority and breadwinning have become influential through the ongoing Islamic revival and Muslim family law's institutionalization in the legal system. Yet these ideals are under threat from social and economic changes that are resulting in women's greater educational attainment and career potential, as well as from competing egalitarian Islamic gender discourses.

This context shapes Muslim households such that married women and men seek to protect or bolster men's status through gendered religious scripts of women's obedience and men's household authority. Women achieve femininity and protect their husbands' masculinity by emphasizing their obedience and underplaying their careers and income earning, while men achieve masculinity through emphasizing their household leaderships and authority over their wives. I argue that this process helps to compensate for the social changes that are putting men's authority at risk - the rhetoric reassures people that the household remains a space of "tradition," 
justified by Islam. For women, the complementarian gender discourses of Islam appeal because they are understood to allow for them to work and seek education, while maintaining a gendered understanding of themselves and their household that does not threaten their husband, their femininity, or their religion. Key to this is that the script of obedience allows them to live up to their ideals of being pious Muslims, something many believers seek in a time of religious revival. As scholars have shown, gendered religious scripts can be flexible, used and interpreted in different ways, and this is true for both the scripts of women's obedience and men's authority.

As women increasingly have the potential to contribute significant income to families, the actual gendered division of labor in households may not necessarily reflect the ideal of male breadwinning and household authority encoded in Indonesia's Islamic family law. Gendered religious scripts may be especially crucial to how people achieve their gendered identities when the conventional gendered order is challenged. Indeed, I propose that in the case of contemporary urban Indonesia, gendered religious scripts are becoming the mechanism to achieve status as Muslim men and women at a time when such status is at risk.

As the public sphere becomes more egalitarian in societies where the dominant interpretation of religion is not egalitarian, religiously justified gender norms may take on greater importance in the household. This process may be especially pronounced in Muslim contexts where particular religious gender discourses are institutionalized and also subject to challenge from socioeconomic changes as well as ideological contestation. For example, Malaysia has institutionalized Islamic law within its governance to a greater extent than Indonesia, and recent years have seen increases in tertiary educational attainment and workforce participation by women. Issues of gender, sexuality, and religious identity have become politicized and the Muslim family has come to be seen as a critical site for the production of a "pure" Islam (Stivens 
2017). In this setting, there is increased pressure for women to adhere to gendered religious norms such as deferring to their husbands' authority.

But these dynamics are also evident in other places where conventional understandings of religion and gender are challenged by economic or social changes. For example, evidence from the US after the recession of 2008 shows that when men lost their jobs, their contribution to domestic and caregiving work remained limited because such work was still considered to be the province of women. Men were focused on maintaining their masculine identities in the absence of employment. Apparently, challenges to men's breadwinner status can actually reinforce traditional gender ideologies (Legerski and Cornwall 2010). This could be one of the reasons for the persistent gendering of household labor (England 2010). Ideological compensation for going against conventional sex/gender norms is not only seen in heterosexual Evangelical couples but can also be seen in LGBTQ affirming congregations where men affirm their masculinity through "manhood acts" that exclude women from power (Sumerau 2012). Promising directions for future research could include studying how gendered religious scripts shape the distribution of household labor and women's career attainment in diverse religious contexts, the dynamics of gendered religious scripts in different kinds of intimate relationships (including LGBTQ relationships); and international comparative investigations of how changes in the public sphere such as increasing women's employment shape the doing of gender and religion in everyday life. 


\section{REFERENCES}

Australia Indonesia Partnership for Economic Governance. 2017. "Women's Economic Participation in Indonesia."

https://www.monash.edu/business/cdes/research/publications/publications2/Womens-economicparticipation-in-Indonesia-June-2017.pdf

Avishai, Orit and Courtney Irby. 2017. "Bifurcated Conversations in Sociological Studies of Religion and Gender.” Gender \& Society 31(5): 647-676

Avishai, Orit. 2016. "Theorizing Gender from Religion Cases: Agency, Feminist Activism, and Masculinity.” Sociology of Religion 77(3): 261-179.

Avishai, Orit, Afshan Jafar, and Rachel Rinaldo. 2015. "A Gender Lens on Religion.” Gender \& Society 29(1): 5-25.

Avishai, Orit. 2008. “'Doing Religion' in a Secular World: Women in Conservative Religions and the Question of Agency." Gender \& Society 22(4): 409-433.

Bahan Penyuluhan Hukum. 2001. Departmen Agama R.I. Direktorat Jenderal Pembinaan Kelembagaan Agama Islam.

Bartkowski, John. 2001. Remaking the Godly Marriage: Gender Negotiation in Evangelical Families. Rutgers University Press.

Bartkowski, John and Jen'nan Ghazal Read. 2003. "Veiled Submission: Gender, Power, and Identity among Evangelical and Muslim Women in the United States." Qualitative Sociology 26(1): 71-92.

Blackburn, Suzanne. 2004. Women and the State in Modern Indonesia. Cambridge University Press.

Boston Consulting Group. 2013. "Indonesia's Rising Middle Class and Affluent Consumers: Asia's Next Big Opportunity."

https://www.bcgperspectives.com/content/articles/center_consumer_customer_insight_consumer _products_indonesias_rising_middle_class_affluent_consumers/

Bowen, John. R. 1986. "On the Political Construction of Tradition: Gotong Royong in Indonesia." The Journal of Asian Studies 45(3): 545-561.

BPS Malang. 2013. Malang Dalam Angka. Malang, Indonesia.

Brasher, Brenda. 1998. Godly Women: Fundamentalism and Female Power. Rutgers University Press. 
Brenner, Suzanne. 1998. The Domestication of Desire: Women, Wealth, and Modernity in Java. Princeton University Press.

. 2011. "Private Moralities in the Public Sphere: Democratization, Islam, and Gender in Indonesia. American Anthropologist 113(3): 478-490.

Bruinessen, Martin, ed. 2013. Contemporary Developments in Indonesian Islam: Explaining the 'Conservative Turn'. Singapore: ISEAS Press.

Burke, Kelsy and Amy Moff Hudec. 2015. "Sexual Encounters and Manhood Acts:

Evangelicals, Latter Day Saints, and Religious Masculinities." Journal for the Scientific Study of Religion 54(2): 330-344.

Burke, Kelsy. 2012. "Women's Agency in Gender-Traditional Religions: A Review of Four Approaches." Social Compass 6(2): 122-133.

Cammack, Mark, Lawrence A. Young and Tim Heaton. 1996. "Legislating Social Change in an Islamic Society: Indonesia's Marriage Law." The American Journal of Comparative Law 44(1): 45-73.

Cammack, Mark and Tim Heaton. 2011. "Explaining the Recent Upturn in Divorce in Indonesia: Developmental Idealism and the Effect of Political Change." Asian Journal of Social Science 39: 776-796.

Cammack, Mark and R. Michael Feener. 2012. "The Islamic Legal System in Indonesia." Pacific Rim Law and Policy Journal 21(1): 13-42.

Cammack, Mark, Adrian Bedner, and Stijn Van Huis. 2015. "Democracy, Islam, and Islamic Family Law in Post-Soeharto Indonesia. New Middle Eastern Studies 5.

http://www.brismes.ac.uk/nmes/archives/1413

Chong, Kelly H. 2008. Deliverance and Submission: Evangelical Women and the Negotiation of Patriarchy in South Korea. Harvard University Press.

Darwin, Helana. 2018. "Redoing Gender, Redoing Religion.” Gender \& Society 32(3): 348-370.

Denton, Melinda Lundquist. 2004. "Gender and Marital Decision-making: Negotiating Religious Ideology and Practice.” Social Forces 82(3): 1151-1180.

Edgell, Penny. 2006. Religion and Family in a Changing Society. Princeton University Press.

England, Paula. 2010. "The Gender Revolution: Uneven and Stalled.” Gender \& Society 24(2): 149-166.

Esposito, John L. and Natana DeLong-Bas. 2001. Women in Muslim Family Law. Syracuse, NY: Syracuse University Press. 
Gallagher, Sally K. and Christian Smith. 1999. "Symbolic Traditionalism and Pragmatic Egalitarianism: Contemporary Evangelicals, Families, and Gender." Gender \& Society 13(2): 211-233.

Gallagher, Sally K. 2003. Evangelical Identity and Gendered Family Life. Rutgers University Press.

Griffith, Marie R. 1997. God's Daughters: Evangelical Women and the Power of Submission. University of California Press.

Irby, Courtney. 2014a. "Dating in Light of Christ: Young Evangelicals Negotiating Gender in the Context of Religious and Secular American Culture." Sociology of Religion 75(2): 260-283.

Irby, Courtney. 2014b. "Moving Beyond Agency: A Review of Gender and Intimate Relationships in Conservative Religions.” Sociology Compass 8(11): 1269-1280.

Legerski, Elizabeth Miklya and Marie Cornwall. 2010. "Working-Class Job Loss, Gender, and the Negotiation of Household Labor.” Gender \& Society 24(4): 447-474.

Mahmood, Saba. 2005. Politics of Piety: The Islamic Revival and the Feminist Subject. Princeton University Press.

Macleod, Arlene E. 1992. "Hegemonic Relations and Gender Resistance: The New Veiling as Accommodating Protest in Cairo.” Signs 17(3). 533-577.

Menchik, Jeremy. 2016. Islam and Democracy in Indonesia: Tolerance without Liberalism. Cambridge University Press.

Mir-Hosseini, Ziba, Mulki al-Sharmani and Jana Rumminger, eds. 2015. Men in Charge? Rethinking Muslim Legal Tradition. London: Oneworld Publications.

Nurlaelawati, Euis. 2010. Modernization, Tradition, and Identity: The Kompilasi Hukum Islam and Legal Practice in the Indonesian Religious Courts. Amsterdam University Press.

Nurlaelawati, Euis. 2013. "Muslim Women in Indonesian Religious Courts: Reform, Strategies, and Pronouncement of Divorce." Islamic Law and Society 20(3): 242-271.

Nyhagen, Line and Beatrice Halsaa. 2016. Religion, Gender, and Citizenship: Women of Faith, Gender, Equality and Feminism. Palgrave Macmillan.

OECD. 2017. "Education at a Glance: Indonesia.” Http://stats.oecd.org.

O'Shaughnessy, Kate. 2009. Gender, State, and Social Power in Contemporary Indonesia: Divorce and Marriage Law. New York and London: Routledge. 
Peletz, Michael. 2009. Gender Pluralism: Southeast Asia since Early Modern Times. New York and London: Routledge.

Predelli, Line Nyhagen. 2004. "Interpreting Gender in Islam: A Case Study of Immigrant Women in Oslo, Norway." Gender \& Society 18(4): 473-493.

Quran.com. “An-Nisa.” https://quran.com/4

Rao, Aliya. 2015. "Gender and Cultivating the Moral Self in Islam: Muslim Converts in an American Mosque." Sociology of Religion 76(4): 413-435.

Rinaldo, Rachel. 2013. Mobilizing Piety: Islam and Feminism in Indonesia. Oxford University Press.

Robinson, Kathryn. 2008. Gender, Islam, and Democracy in Indonesia. London and New York: Routledge.

Rosser, Andrew. 2018. "Beyond Access: Making Indonesia's Educational System Work.” Lowy Institute Analyses. https://www.lowyinstitute.org/publications/beyond-access-making-indonesias-education-system-work

Schaner, Simone and Smita Das. 2016. "Female Labor Force Participation in Asia: Indonesia Country Study.” Asian Development Bank Economics Working Paper Series \#474.

Sidel, John Thayer. 2006. Riots, Pogroms, Jihad: Religious Violence in Indonesia. Ithaca, NY: Cornell University Press.

Small, Mario L. 2009. "How Many Cases do I Need? On Science and the Logic of Case Selection in Field Research. Ethnography 10(1): 5-38.

Stivens, Maila. 2017. “Making Spaces in Malaysia: Women's Rights and New Muslim Religiosities." In Jose Casanova and Jocelyn Cesari, eds. Islam, Gender, and Democracy in Comparative Perspective. Oxford University Press.

Sullivan, Norma. 1994. Masters and Managers: A Study of Gender Relations in Urban Java. Sydney, Australia: Allen and Unwin.

Tickamyer, Ann R. and Siti Kusujiarti. 2012. Power, Change, and Gender Relations in Rural Java. Ohio University Press.

Tucker, Judith E. 2008. Women, Family, and Gender in Islamic Law. Cambridge University Press.

UNESCO Institute for Statistics. 2016. “Education.” Retrieved May 30, 2016. http://data.uis.unesco.org/?queryid=142 
Utomo, Ariane. 2015. “A Woman's Place.” Inside Indonesia 120.

http://www.insideindonesia.org/a-woman-s-place-3

Utomo, Ariane J. 2016. "Gender in the Midst of Reforms: Attitudes to Work and Family Roles among University Students in Urban Indonesia." Marriage and Family Review 52(5): 421-441.

Van Huis, Stijn. 2015. "Islamic Courts and Women's Divorce Rights in Indonesia: The Cases of Cianjur and Bulukumba." Unpublished PhD dissertation, Leiden University.

Welchman, Lynn. 2011. "A Husband's Authority: Emerging Formulations in Muslim Family Laws.” International Journal of Law, Policy, and the Family 25(1): 1-23.

West, Candace and Don Zimmerman. “Doing Gender.” Gender \& Society 1(2): 125-151.

Wilcox, W. Bradford. 2004. Soft Patriarchs, New Men: How Christianity Shapes Fathers and Husbands. University of Chicago Press.

World Bank. 2016. "Indonesia's Rising Divide.” Washington, D.C. World Bank Group. http://documents.worldbank.org/curated/en/267671467991932516/Indonesias-rising-divide.

\footnotetext{
i Non-Muslim family matters are overseen by civil (secular) courts.

ii Prior to 1991, some Muslims also used religious courts for family law matters, but many also pursued these matters less formally through local religious leaders. The 1991 Compilation standardized the interpretation of Islamic law applied to family matters in the religious courts and required Muslims to register marriages and pursue divorce and inheritance cases through the religious courts.

iii Van Huis (2015) notes that spousal responsibilities under the 1974 Marriage Law were until recently listed on marriage certificates.

iv In most versions of Muslim family law, including the Compilation of Islamic Law, family maintenance (nafkah) is considered to be the responsibility of the husband and the wife is free to use her income as she chooses. Indonesia also wives frequently manage the household finances.
} 